\title{
"Measuring Involvement for Organic Food Products: Testing and Identifying the Variables Affecting Consumer Involvement in Selected Urban Dwellings of Gujarat"
}

\author{
Ashwini Joshi ${ }^{1}$, Amol Ranadive ${ }^{2}$ \\ ${ }^{1}$ Research Scholar, School of Business \& Law, Navrachana University, Vadodara, India. \\ ${ }^{2}$ Associate Professor, School of Business \& Law, Navrachana University, Vadodara, India.
}

\begin{abstract}
The main aim of this research was to first design, test and validate a structured tool to measure the construct of consumer involvement for organic food products. To do this, three most populated urban dwellings in the state of Gujarat, India were surveyed. A total sample of 200 respondents was deemed appropriate in terms of the validity of results as well as resources at hand. The three urban dwellings covered under this study were Ahmedabad, Surat and Vadodara. Out of the total sample size, 80 valid responses were collected from Ahmedabad, 70 from Surat and 50 from Vadodara. Initially, a structured tool was developed keeping in mind four basic dimensions which were, Information Search, Affection, Importance and Purchase. The tool had twenty statements asking for respondents' opinion on a five-point Likert scale ranging from 'Strongly Agree' to 'Strongly Disagree'. Apart from this the questionnaire collected demographic data of the respondents. After collecting data, using factor analysis, four antecedents of involvement were validated since the Eigenvalues for each of them were above 1. Overall, these four antecedents or factors explained $65.71 \%$ of the total variance. After statistically validating the tool, consumer involvement was measured and results showed moderately higher involvement. Further analysis was carried out to understand the inter-relationship between the antecedents inter-alia and consumer involvement. Correlation analysis confirmed strong positive correlation between all the antecedents as well as between consumer involvement and its antecedents which further confirmed the validity of this tool. Since correlation was found to be highly positive and significant, it was considered appropriate to establish and test this construct using regression analysis. Regression analysis revealed that all the antecedents had more or less similar impact on consumer involvement for organic food products.
\end{abstract}

Keywords - Involvement, Information Search, Knowledge, Belief, Emotion.

\section{INTRODUCTION}

India is primarily an agrarian economy. Since independence, majority of the population depended on agriculture for their subsistence. With the passage of time, this proportion has decreased but still, agriculture dominates Indian Economy. With the modernisation and economic development, India has taken large strides in adopting new methods of agriculture. One major criticism of this modernisation was the extensive use of pesticides and fertilizers. Over a period of time from the 1960s, such unchecked use of chemical elements has led to health problems. Now, with the awareness about health and environment rising, people have started searching for healthy options. The solution to their problem was discovered in organic food products. These products are grown under an agricultural technique where there is no use of harmful chemical fertilizers and pesticides. This technique aims at conserving the natural capacity and productivity of soil, nutrition and soil management. Even the government of India has taken some initiatives by implementing the National Programme for Organic Production (NPOP), which includes establishment of certifying agencies, organic production standards and promoting organic farming amongst others.

The idea of involvement has its origins in the field of psychology. Initially this concept was used to understand the receptivity of individuals on communications. Later, this concept was brought into the study of consumer behaviour. Initially, the aim of lot of research studies was to conceptualise and define involvement with reference to advertisements, products and even situations. Different researchers provided varied perspectives to this concept. Later on, some researchers tried to create a construct by which involvement could be measured. 
DOI: $\underline{10.51386 / 25815946 / \mathrm{ijsms}-\mathrm{v} 4 \mathrm{i} 4 \mathrm{p} 139}$

Volume: 4 Issue: 4

July to August 2021

https://www.ijsmsjournal.org

Some of the notable contributors were Laurent and Kapferer, Kassarjian and Zaichkowsky. Zaichkowsky created a tool to measure involvement in the year 1985 which was called the personal involvement inventory (PII). It was later revised and the revised personal involvement inventory (RPII) was tested. As mentioned earlier, involvement has been defined by various researchers from different facets, the definition of involvement considered appropriate in this research was "a person's perceived relevance of the object based on inherent needs, values and interests" (Zaichkowsky, 1985) ${ }^{1}$. Involvement levels have been found to have a significant impact on the buying process that consumers undertake. It has been observed that in case of products where the involvement levels are high, consumer perceives high risk and accordingly higher levels of satisfaction are expected. Conversely, if wrong purchasing decision is made it involves larger amounts of risks with reference to the price paid, time and satisfaction. As a result, consumer spends more time in information search and undertakes meticulous evaluation of alternatives before arriving at purchase decisions.

This research paper aims at examining the product involvement levels for organic food products in selected urban dwellings of Gujarat. Not just involvement, the focus was also to identify, test and validate antecedents of product involvement.

\section{REVIEW OF LITERATURE}

Both, the concept of involvement as well as organic food products are relatively novel. Especially, when it comes to the scenario in India, the latter concept is still in its nascent stage. In the beginning, there was a lot of debate especially on the definition of involvement and later on the overall construct of involvement. Therefore, a major part of initial researches was focussed on clearing the air in this regard. According to Salmon $(1986)^{2}$, involvement can be considered as an interface between an individual and the product. Even though in most of the cases, involvement is considered as product relevance instead of individual's interest in a product, it can be interpreted more as a stimulus. Muncy and Hunt $(1984)^{3}$ identified five types of involvement which were pronounced as ego involvement, commitment, communication involvement and purchase importance. Assael $(1981)^{4}$, tried to conceptualise high involvement and low involvement. Purchases which are important to a consumer can be put under the category of high involvement. Involvement levels affect brand perceptions also. When involvement is low, researchers have observed a behaviour wherein the consumers engage highly when it comes to posts about the brand itself. On the other side, for high involvement products or brands, they like to share the brand content (Barreto \&Ramalho, 2019) $)^{5}$.Involvement has been found to have a significant impact on prediction of brand loyalty (Sridharan et.al., 2008) ${ }^{6}$. The idea of organic food product consumption is to a great extent related to health risks. Conventional foods have been found to be adversely affecting health due to the extensive use of pesticides and chemical fertilizers in them. The use of GMO (Genetically Modified Organisms) in farming is also highly debatable. Looking at these issues with conventional foods, the concept of involvement becomes relevant to organic food products. Boote et.al., (2002) ${ }^{7}$ discussed the concept of consumer involvement in the backdrop of health research. They identified the reasons for considering consumer involvement to be appropriate for health research. The implication of the concept of involvement was further utilised in the field of consumer behaviour by considering high, moderate and low involvement for wine as a market segmentation strategy by Koksal $(2020)^{8}$. Rachmawati and Suroso $(2020)^{9}$ examined the relationship between knowledge about a product and involvement levels with regard to purchase decision. It was inferred that consumer involvement and product knowledge positively impact the buying decision process of a consumer. According to

\footnotetext{
1 Zaichkowsky, J. L. (1985). Measuring the involvement construct. Journal of Consumer Research, 12, 341-352. https://doi.org/10.1086/208520

${ }^{2}$ Salmon, C.T. (1986). Perspectives on involvement in consumer and communication research. Progress in communication sciences, 7,243268.

${ }^{3}$ J., A., Muncy and S., D., Hunt. (1984). Consumer Involvement: Definitional Issues and research directions. Advances in Consumer Research, 11, 193-196. DOI: https://www.acrwebsite.org/volumes/6241/volumes/v11/NA-11.

${ }_{5}^{4}$ H., Assael. (1981). Consumer Behaviour and Executive Action. Boston: Kent

${ }^{5}$ Barreto, A.M. and Ramalho, D. (2019). The Impact of Involvement on Engagement with Brand Posts. Journal of Research in Interactive Marketing, 13(3), 277-301. DOI: https://doi.org/10.1108/JRIM-01-2018-0013

${ }^{6}$ Sridharan, R., Jyothi, K. T. and Rajakumar, C.S. (2008). Role of Involvement in Predicting Brand Loyalty. Asia Pacific Business Review, 4(1), 44-58. DOI: https://doi.org/10.1177/097324700800400105

${ }^{7}$ J., Boote, T., Rosemary and C., Cindy. (2002). Consumer Involvement in Health Research: A Review and Research Agenda. Health Policy (Amsterdam, Netherlands), 61, 213-236. DOI: 10.1016/S0168-8510(01)00214-7.

${ }^{8}$ Koksal, M., H. (2020). Segmentation of Wine Consumers based on level of involvement: A Case of Lebanon. British Food Journal, 123(3), 926-942. DOI: https://doi.org/10.1108/BFJ-03-2020-0183

${ }^{9}$ Rachmawati, E., S. and Suroso, A. (2020). A Moderating Role of Halal Brand Awareness to Purchase Decision Making. Journal of Islamic Marketing, Vol. ahead-of-print. DOI: https://doi.org/10.1108/JIMA-05-2020-0145
} 
DOI: $\underline{10.51386 / 25815946 / \mathrm{ijsms}-\mathrm{v} 4 \mathrm{i} 4 \mathrm{p} 139}$

Jian Mou et.al. (2019) ${ }^{10}$, a product with higher quality has a favourable effect on different types of involvement like cognitive, affective, enduring and situational involvement. Involvement was found to have a positive impact on purchasing intention for the product.

\section{III.RESEARCH METHODOLOGY}

The main purpose of this research was to identify antecedents of involvement through testing and validating variables which were based on pre-defined dimensions. Based on the findings of similar researches, four dimensions were identified as Information Search, Affection, Importance and Purchase. A structured tool was developed on the basis of these dimensions and data was collected from 200 respondents across three major urban centres in the state of Gujarat, India. These cities were Ahmedabad, which is the city with the largest urban population in the state, Surat, which is also the textile capital and a diamond industry hub in India and Vadodara which is also called the cultural capital of the state. The total sample size of 200 was distributed between these three major cities relatively in proportion to their urban population. Accordingly, data was collected from 80 respondents from Ahmedabad, 70 from Surat and 50 from Vadodara. For selecting the samples, stratified random sampling technique was used where occupation of the respondents was considered as the strata. The structured questionnaire which was designed was divided into two parts. The first part contained statements asking opinion of respondents on a 5-point Likert scale where 5 was "Strongly Agree" and 1 was "Strongly Disagree". The statements were framed covering the four dimensions of consumer involvement mentioned earlier. The second part of the questionnaire collected information regarding the demographic details of the respondents. In this research, consumer involvement was considered to be the dependent variable and its antecedents along with demographics of the respondents were considered to be independent variables.

After collecting the data, before conducting further analysis, the reliability of results was examined and the obtained Cronbach alpha value was 0.921 . Technically, Cronbach alpha values more than 0.60 are considered reliable. Therefore, the preliminary value obtained in this research suggested that the data could be further analysed to test the objectives of this research.

\section{IV.OBJECTIVES}

- To identify variables leading to product involvement for organic food products.

- To test and validate the tool for measuring product involvement for organic food products based on the variables identified.

- To examine the inter-relationship between the identified and validated variables affecting product involvement for organic food products.

- To measure product involvement level for organic food products in urban dwellings of Gujarat.

- To propose a model for measurement of product involvement for organic food products.

\section{HYPOTHESIS}

On the basis of the objectives of this research, the following hypothesis was formulated.

$\mathbf{H}_{0}$ : There is lack of significant product involvement for organic food products in selected urban dwellings of Gujarat.

\section{VI.DISCUSSION}

The data collected from across the three cities of Gujarat was found reliable for further analysis. In view of the objectives of this research, initially an attempt was made to identify variables that lead to high or low product involvement for organic food products. For this, confirmatory factor analysis (Principal Axis Factoring) was carried out.

Table 1. KMO and Bartlett's Test for validating antecedents of consumer involvement for organic food products in selected urban dwellings of Gujarat.

\begin{tabular}{|l|l|r|}
\hline K-M-O Measure of Sampling Adequacy. & 0.910 \\
\hline \multirow{2}{*}{$\begin{array}{l}\text { Bartlett's Test } \\
\text { of Sphericity }\end{array}$} & Approx. Chi-Square & 6856.692 \\
\cline { 2 - 3 } & df & 190 \\
\cline { 2 - 3 } & Sig. & 0.000 \\
\hline
\end{tabular}

\footnotetext{
${ }^{10}$ Mou, J., Zhu, W. and Benyoucef, M. (2019). Impact of Product Description and Involvement on Purchase Intention in Cross-Border ECommerce. Industrial Management \& Data Systems, 120(3), 567-586. DOI: https://doi.org/10.1108/IMDS-05-2019-0280
} 
DOI: $\underline{10.51386 / 25815946 / \mathrm{ijsms}-\mathrm{v} 4 \mathrm{i} 4 \mathrm{p} 139}$

Volume: 4 Issue: 4

July to August 2021

https://www.ijsmsjournal.org

Table 1. shows the adequacy and reliability of the data. The Kaiser-Meyer-Olkin (KMO) is a preliminary test that statistically establishes whether the data collected is fit for conducting factor analysis (Dodge, 2008) $)^{11}$. KMO values which are near to 1 indicate data suitability. In this research, a KMO value of 0.910 indicated that the results were safely within the acceptable range which is considered to be above 0.50 . The second test which was the Bartlett's Test of Sphericity indicates whether the variables considered for a research are related or not. Statistically, significance values of less than 0.05 indicate that data can be used for factor analysis. In this research, the Chi-square value of 6586.692 with degree of freedom 190 and significance of 0.000 meant that all the variables considered had high correlation amongst them. So, based on the results of Table 1., it was observed that the data was fit for factor analysis.

Table 2. Communalities

\begin{tabular}{|c|r|r|}
\hline Item & \multicolumn{1}{|c|}{ Initial } & Extraction \\
\hline 1 & 0.60 & 0.561 \\
\hline 2 & 0.581 & 0.672 \\
\hline 3 & 0.53 & 0.46 \\
\hline 4 & 0.709 & 0.681 \\
\hline 5 & 0.583 & 0.555 \\
\hline 6 & 0.63 & 0.571 \\
\hline 7 & 0.56 & 0.566 \\
\hline 8 & 0.476 & 0.339 \\
\hline 9 & 0.654 & 0.763 \\
\hline 10 & 0.734 & 0.793 \\
\hline 11 & 0.708 & 0.731 \\
\hline 12 & 0.600 & 0.572 \\
\hline 13 & 0.675 & 0.665 \\
\hline 14 & 0.553 & 0.51 \\
\hline 15 & 0.587 & 0.509 \\
\hline 16 & 0.282 & 0.300 \\
\hline 17 & 0.692 & 0.704 \\
\hline 18 & 0.462 & 0.453 \\
\hline 19 & 0.561 & 0.562 \\
\hline 20 & 0.481 & 0.496 \\
\hline Extraction Method: Principal Axis Factoring. \\
\hline
\end{tabular}

Table 3. Factor Analysis for testing and validating antecedents of involvement towards organic food products in selected urban dwellings of Gujarat.

\begin{tabular}{|c|c|c|c|c|c|c|c|c|c|}
\hline \multirow{2}{*}{$\begin{array}{c}\text { Facto } \\
\mathbf{r}\end{array}$} & \multicolumn{3}{|c|}{ Initial Eigenvalues } & \multicolumn{3}{|c|}{$\begin{array}{l}\text { Extraction Sums of } \\
\text { Squared Loadings }\end{array}$} & \multicolumn{3}{|c|}{$\begin{array}{c}\text { Rotation Sums of Squared } \\
\text { Loadings }\end{array}$} \\
\hline & Total & $\begin{array}{l}\% \text { of } \\
\text { Var. }\end{array}$ & Cum.\% & Total & $\begin{array}{l}\% \text { of } \\
\text { Var. }\end{array}$ & $\underset{\%}{\text { Cum. }}$ & Total & $\begin{array}{l}\% \text { of } \\
\text { Var. }\end{array}$ & $\underset{\%}{\text { Cum. }}$ \\
\hline 1 & 9.234 & 46.17 & 46.17 & 8.837 & $\begin{array}{r}44.18 \\
3\end{array}$ & 44.183 & 3.979 & 19.893 & 19.893 \\
\hline 2 & 1.764 & 8.82 & 54.99 & 1.328 & 6.638 & 50.821 & 3.231 & 16.155 & 36.049 \\
\hline 3 & 1.085 & 5.425 & 60.415 & 0.677 & 3.387 & 54.208 & 2.146 & 10.729 & 46.777 \\
\hline 4 & 1.059 & 5.295 & 65.71 & 0.624 & 3.122 & 57.33 & 2.111 & 10.553 & 57.33 \\
\hline 5 & 0.875 & 4.377 & 70.087 & & & & & & \\
\hline 6 & 0.725 & 3.627 & 73.715 & & & & & & \\
\hline 7 & 0.698 & 3.492 & 77.206 & & & & & & \\
\hline 8 & 0.629 & 3.146 & 80.352 & & & & & & \\
\hline 9 & 0.567 & 2.833 & 83.185 & & & & & & \\
\hline
\end{tabular}

${ }^{11}$ Stephanie Glen, "Kaiser-Meyer-Olkin" (KMO) Test for Sampling Adequacy from Statistics How To: Elementary Statistics for the rest of us! https://www.statisticshowto.com/kaiser-meyer-olkin/ 
DOI: $\underline{10.51386 / 25815946 / \mathrm{ijsms}-\mathrm{v} 4 \mathrm{i} 4 \mathrm{p} 139}$

Volume: 4 Issue: 4

July to August 2021

https://www.ijssmsjournal.org

\begin{tabular}{|r|r|r|r|l|l|l|l|l|l|}
\hline 10 & 0.489 & 2.444 & 85.629 & & & & & & \\
\hline 11 & 0.444 & 2.219 & 87.848 & & & & & & \\
\hline 12 & 0.413 & 2.066 & 89.914 & & & & & & \\
\hline 13 & 0.34 & 1.7 & 91.614 & & & & & & \\
\hline 14 & 0.336 & 1.678 & 93.292 & & & & & & \\
\hline 15 & 0.294 & 1.468 & 94.759 & & & & & & \\
\hline 16 & 0.282 & 1.412 & 96.171 & & & & & & \\
\hline 17 & 0.227 & 1.137 & 97.308 & & & & & & \\
\hline 18 & 0.198 & 0.991 & 98.299 & & & & & & \\
\hline 19 & 0.185 & 0.927 & 99.226 & & & & & & \\
\hline 20 & 0.155 & 0.774 & 100 & & & & & & \\
\hline
\end{tabular}

Factor analysis considers variance and covariance between variables. Along with this variance correlation is also considered. Technically, higher the correlation between the variables, higher would be the conduciveness for performing the factor analysis. In this research, both the KMO and the Bartlett's test gave highly significant values. Based on those values, it was thought fit to conduct factor analysis using principal axis factoring method. The reason for using principal axis factoring method was that, the initial extraction for communalities as shown in Table 2 is not 1 . Further, principal axis factoring method uses squared multiple correlation coefficient $\left(\mathrm{R}^{2}\right)$ as the initial communality. Table 3 provides the summarised information regarding the antecedents which were revealed. Of the 20 items, four items had Eigenvalues exceeding 1 . As is the case on factor analysis, the first factor explained the maximum variance (46.17\%). The second factor contributed $8.82 \%$ of the total variance. The third and the fourth factor explained $5.425 \%$ and $5.295 \%$ respectively. In all, $65.71 \%$ variance was contributed by these four factors. This proportion is considered as a valid value for researches in the field of consumer behaviour (Yong \& Pearce, 2013) ${ }^{12}$. Based on Eigenvalues, four factors were identified which were also considered as antecedents of involvement. In order to allocate each item from the structured tool to these four antecedents, rotated component factor matrix was used.

Table 4. Rotated Component Matrix (Factors Identified) for testing and validating antecedents of consumer involvement for organic food products in selected urban dwellings of Gujarat.

\begin{tabular}{|c|c|c|c|c|c|}
\hline \multirow{2}{*}{$\begin{array}{l}\text { Sr. } \\
\text { No. }\end{array}$} & \multirow{2}{*}{ Item } & \multicolumn{4}{|c|}{ Factor } \\
\hline & & 1 & 2 & 3 & 4 \\
\hline 1 & I don't mind spending money on OFP. & 0.465 & & 0.494 & \\
\hline 2 & $\begin{array}{l}\text { Using OFPs gives me a feeling of security from pesticides/hazardous substances used in } \\
\text { cultivation/production of CFPs. }\end{array}$ & & 0.375 & 0.679 & \\
\hline 3 & I would prefer OFPs over CFPs in any situation & 0.353 & 0.378 & 0.387 & \\
\hline 4 & I am interested in OFPs & 0.395 & 0.386 & 0.424 & 0.442 \\
\hline 5 & $\begin{array}{l}\text { I read all available information from magazines / internet / other sources to keep myself } \\
\text { abreast with latest developments about OFPs. }\end{array}$ & 0.620 & & & \\
\hline 6 & I am interested in expert's evaluations' and comments on OFPs. & 0.571 & 0.445 & & \\
\hline 7 & I would like to know how OFPs are cultivated / produced. & & 0.595 & & \\
\hline 8 & I think there is a lot of difference between OFPs and CFPs. & & & 0.410 & \\
\hline 9 & I enjoy talking with people who possess knowledge about OFPs. & 0.407 & & & 0.736 \\
\hline
\end{tabular}

${ }^{12}$ An Gie Yong \& Sean Pearce. (2013). A Beginner's Guide to Factor Analysis: Focussing on Exploratory Factor Analysis. Tutorials in Quantitative Methods for Psychology, Vol.9(2), 79-94. DOI: 10.20982/tqmp.09.2.p079 
DOI: $\underline{10.51386 / 25815946 / \mathrm{ijsms}-\mathrm{v} 4 \mathrm{i} 4 \mathrm{p} 139}$

Volume: 4 Issue: 4

July to August 2021

https://www.ijsmsjournal.org

\begin{tabular}{|c|c|c|c|c|c|}
\hline 10 & I like to talk about OFPs with my relatives and friends. & 0.829 & & & \\
\hline 11 & In general, I like to discuss about OFPs over social media platforms. & 0.784 & & & \\
\hline 12 & I could read for quite a while without getting bored. & 0.606 & & & \\
\hline 13 & I think that OFPs are important for everyone. & & 0.423 & 0.461 & 0.493 \\
\hline 14 & I feel that consuming OFPs is an important social advancement. & & 0.536 & & \\
\hline 15 & I like to know opinion on OFPs from people who are interested. & 0.498 & & & \\
\hline 16 & I feel that lot of people are misinformed about OFPs. & 0.391 & & & \\
\hline 17 & I would like to purchase/consume/use OFPs. & & 0.406 & 0.368 & 0.589 \\
\hline 18 & I would choose OFPs instead of CFPs if price for both is the same. & & 0.607 & & \\
\hline 19 & I will definitely buy OFPs if I can afford them. & & 0.695 & & \\
\hline 20 & I avoid food products containing substances which are harmful to human beings. & 0.416 & 0.545 & & \\
\hline \multicolumn{2}{|c|}{$\frac{1}{\text { Eigenvalues }}$} & 9.234 & 1.764 & 1.085 & 1.059 \\
\hline \multicolumn{2}{|c|}{$\%$ of Variance } & 46.170 & 8.820 & 5.425 & 5.295 \\
\hline \multirow{2}{*}{\multicolumn{2}{|c|}{$\begin{array}{l}\text { Cumulative \% } \\
\text { Extraction Method: Principal Axis Factoring. } \\
\text { Rotation Method: Varimax with Kaiser Normalization. } \\
\text { Rotation converged in } 17 \text { iterations. } \\
\text { CFPs- Conventional Food Products }\end{array}$}} & 46.170 & 54.990 & 60.415 & 65.710 \\
\hline & & & & & \\
\hline
\end{tabular}

Table 4. provides details of items allocated to each of the antecedents based on their factor loadings. While running rotated factor matrix, those items which had factor loadings less than 0.35 were ignored since it was presumed that those items would have no influence on the study. After considering these parameters, all 20 items considered in the tool were found valid since all the items had factor loading s above 0.35. After allocating the items to the four antecedents identified earlier, the four dimensions on the basis of which the initial tool was designed were renamed on the basis of re-allocation of the items. The four antecedents which were identified in Table 3, were named as -

i. Information Search (IS) - The degree of personal relevance is critical in explaining how motivated an individual is in searching for information. In case of those products which are of high personal importance, a consumer will be motivated to carry out detailed information search (Petty, Unnava, \& Strathman 1991 ${ }^{13}$; Schiffman \& Kanuk $\left.1994^{14}\right)$.

ii. Knowledge $(\mathrm{K})$ - Knowledge and consumer involvement have a direct relationship. More is the knowledge about a product or service, higher will be the consumer involvement (Ying-Ping Liang, 2012) ${ }^{15}$.

iii. Belief (B) - According to Park, Mothersbaugh and Seick (1994) ${ }^{16}$, beliefs are related to knowledge.

Knowledge creates beliefs about product or service. In case of high consumer involvement, it is likely that higher attention will be paid to product information ${ }^{17}$.

iv. Emotion (E) - Emotion can be triggered by a product especially in case of food products, emotional reactions for high involvement products are mostly positive (Desmet \& Schifferstein, 2008) ${ }^{18}$.

The next table i.e., Table 5. shows the rotated component matrix with all the items re-aligned to each identified antecedent viz., IS, K, B, E.

\footnotetext{
${ }^{13}$ Petty, R.E., Unnava, R.H. \& Strathman, A.J. (1991). Theories of Attitude Change in Thomas S. Robertson and Harold H. Kasaarjian (Eds), Handbook of Consumer Behaviour, Englewood Cliffs NJ: Prentice Hall.

${ }^{14}$ Schiffman, L.G. and Kanuk, L.L. (1994) Consumer Behaviour. Prentice-Hall, Englewood Cliffs.

${ }^{15}$ Ying-Ping Liang. (2012). The Relationship between Consumer Product Involvement, Product Knowledge and Impulsive Buying Behaviour. Procedia - Social and Behavioural Sciences, Vol.57, 325-330. https://doi.org/10.1016/j.sbspro.2012.09.1193

${ }^{16}$ C. Whan Park, David L. Mothersbaugh and Lawrence Seick. (1994). Consumer Knowledge Assessment. Journal of Consumer Research, Vol.21(1), 71-82. https://doi.org/10.1086/209383

${ }^{17}$ Assael, H. (1998). Consumer Behaviour and Marketing Action. South-Western College Publishing: International Thomson Publishing.

${ }^{18}$ Desmet P., M, and Schifferstein H., N. (2008). Sources of Positive and Negative Emotions in Food Experience. Appetite, Vol.50(2-3), 290-301. DOI: 10.1016/j.appet.2007.08.003.Epub 2007 Aug 28.PMID:17945385.
} 
DOI: $\underline{10.51386 / 25815946 / \mathrm{ijsms}-\mathrm{v} 4 \mathrm{i} 4 \mathrm{p} 139}$

Table 5. Rotated Component Matrix (Factors Named) for testing and validating antecedents of consumer involvement for organic food products in selected urban dwellings of Gujarat.

\begin{tabular}{|c|c|c|c|c|c|}
\hline Factor & Item & $\begin{array}{l}\text { Factor } \\
\text { Loading }\end{array}$ & Cronbach & Mean & S.D. \\
\hline \multirow{7}{*}{$\begin{array}{l}\text { Information } \\
\text { Search (IS) }\end{array}$} & $\begin{array}{l}\text { I read all available information from magazines / internet / } \\
\text { other sources to keep myself abreast with latest developments } \\
\text { about OFPs. }\end{array}$ & 0.62 & \multirow{7}{*}{0.825} & \multirow{7}{*}{3.65} & \multirow{7}{*}{1.111} \\
\hline & $\begin{array}{l}\text { I am interested in expert's evaluations' and comments on } \\
\text { OFPs. }\end{array}$ & 0.571 & & & \\
\hline & I like to talk about OFPs with my relatives and friends. & 0.829 & & & \\
\hline & $\begin{array}{l}\text { In general, I like to discuss about OFPs over social media } \\
\text { platforms. }\end{array}$ & 0.784 & & & \\
\hline & I could read for quite a while without getting bored. & 0.606 & & & \\
\hline & $\begin{array}{l}\text { I like to know opinion on OFPs from people who are } \\
\text { interested. }\end{array}$ & 0.498 & & & \\
\hline & I feel that lot of people are misinformed about OFPs. & 0.391 & & & \\
\hline \multirow{5}{*}{$\begin{array}{l}\text { Knowledge } \\
\text { (K) }\end{array}$} & I would like to know how OFPs are cultivated / produced. & 0.595 & \multirow{5}{*}{0.75} & \multirow{5}{*}{4.16} & \multirow{5}{*}{0.888} \\
\hline & $\begin{array}{l}\text { I feel that consuming OFPs is an important social } \\
\text { advancement. }\end{array}$ & 0.536 & & & \\
\hline & $\begin{array}{l}\text { I would choose OFPs instead of CFPs if price for both is the } \\
\text { same. }\end{array}$ & 0.607 & & & \\
\hline & I will definitely buy OFPs if I can afford them. & 0.695 & & & \\
\hline & $\begin{array}{l}\text { I avoid food products containing substances which are } \\
\text { harmful to human beings. }\end{array}$ & 0.545 & & & \\
\hline \multirow{4}{*}{$\begin{array}{l}\text { Belief } \\
\text { (B) }\end{array}$} & I don't mind spending money on OFP. & 0.494 & \multirow{4}{*}{0.75} & \multirow{4}{*}{4.08} & \multirow{4}{*}{0.903} \\
\hline & $\begin{array}{l}\begin{array}{l}\text { Using OFPs gives me a feeling of } \\
\text { pesticides/hazardous security } \\
\text { substances }\end{array} \\
\text { cultivation/production of CFPs. }\end{array}$ & 0.679 & & & \\
\hline & I would prefer OFPs over CFPs in any situation & 0.387 & & & \\
\hline & I think there is a lot of difference between OFPs and CFPs. & 0.41 & & & \\
\hline \multirow{4}{*}{$\begin{array}{l}\text { Emotion } \\
(\mathbf{E})\end{array}$} & I am interested in OFPs & 0.442 & \multirow{4}{*}{0.797} & \multirow{4}{*}{3.995} & \multirow{4}{*}{0.943} \\
\hline & $\begin{array}{l}\text { I enjoy talking with people who possess knowledge about } \\
\text { OFPs. }\end{array}$ & 0.736 & & & \\
\hline & I think that OFPs are important for everyone. & 0.493 & & & \\
\hline & I would like to purchase/consume/use OFPs. & 0.589 & & & \\
\hline
\end{tabular}

S.D. = Standard Deviation

Table 5 provides detailed information about various items under each antecedent of involvement along with their factor loading. Cronbach alpha value of each factor or antecedent is above 0.60 which confirms reliability of the tool. For the first factor Information Search (IS), the Cronbach alpha was obtained at 0.825 which was the highest. While for the factors Knowledge (K) and Belief (B) the alpha values were 0.75 . For the factor emotion, the alpha value was 0.797 . Based on these values, it could be inferred that the results obtained were conducive for further interpretation. Table 5 also provides mean values for each of the antecedent. These values ranged between 4.16 for Knowledge and 3.65 for the factor Information Search (IS). The values obtained suggested moderately higher values leading to consumer involvement. The overall consumer involvement for organic food products based on the antecedents identified earlier was observed to be 3.97. This value on a 5-point scale also hinted at moderately higher involvement. 
DOI: $\underline{10.51386 / 25815946 / \mathrm{ijsms}-\mathrm{v} 4 \mathrm{i} 4 \mathrm{p} 139}$

Figure 1. Research Construct

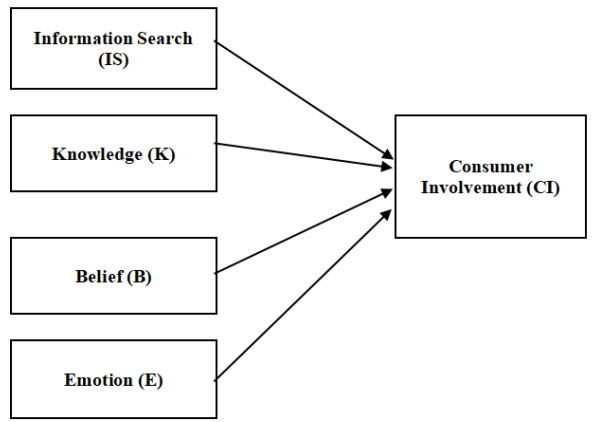

Figure 1 explains consumer involvement formation for organic food products in urban dwellings of Gujarat based on its antecedents viz., Information Search (IS), Knowledge (K), Belief (B) and Emotion (E). Based on these antecedents, the hypothesis for this research was examined which is provided in the following Table 6.

Table 6. Consumer Involvement for organic food products based on its antecedents in selected urban dwellings of Gujarat

\begin{tabular}{|c|c|c|c|c|c|c|c|}
\hline \multirow{2}{*}{ Factor } & & \multicolumn{3}{|c|}{ Mean } & \multirow{2}{*}{$\begin{array}{l}\text { Overall } \\
\text { Mean }\end{array}$} & \multirow{2}{*}{$\begin{array}{c}\text { Chi } \\
\text { Square }\end{array}$} & \multirow{2}{*}{ Sig. } \\
\hline & & $\begin{array}{c}\text { Ahmed } \\
\text { abad }\end{array}$ & Surat & $\begin{array}{c}\text { Vadodar } \\
\mathbf{a}\end{array}$ & & & \\
\hline \multirow{2}{*}{$\begin{array}{l}\text { Information Search } \\
\text { (IS) }\end{array}$} & Mean & 3.67 & 3.69 & 3.53 & 3.64 & \multirow[b]{2}{*}{86.250} & \multirow[b]{2}{*}{0.000} \\
\hline & S.D. & 0.7503 & 0.7807 & 0.7684 & 0.7646 & & \\
\hline \multirow{2}{*}{$\begin{array}{l}\text { Knowledge } \\
\text { (K) }\end{array}$} & Mean & 4.07 & 4.21 & 4.26 & 4.16 & \multirow[b]{2}{*}{111.780} & \multirow[b]{2}{*}{0.000} \\
\hline & S.D. & 0.7549 & 0.5506 & 0.5437 & 0.6410 & & \\
\hline \multirow{2}{*}{$\begin{array}{l}\text { Belief } \\
\text { (B) }\end{array}$} & Mean & 4.03 & 4.05 & 4.11 & 4.06 & \multirow[b]{2}{*}{122.840} & \multirow[b]{2}{*}{0.000} \\
\hline & S.D. & 0.7023 & 0.7155 & 0.6471 & 0.6909 & & \\
\hline \multirow{2}{*}{$\begin{array}{l}\text { Emotion } \\
\text { (E) }\end{array}$} & Mean & 4.05 & 3.92 & 4.09 & 4.01 & \multirow[b]{2}{*}{166.940} & \multirow[b]{2}{*}{0.000} \\
\hline & S.D. & 0.7772 & 0.7206 & 0.6947 & 0.7375 & & \\
\hline \multirow{2}{*}{ Consumer Involvement } & Mean & 3.95 & 3.96 & 3.99 & 3.96 & \multirow[b]{2}{*}{63.34} & \multirow[b]{2}{*}{0.000} \\
\hline & S.D. & 0.6356 & 0.5718 & 0.5988 & 0.6019 & & \\
\hline
\end{tabular}

S.D. $=$ Standard Deviation, Sig. $=$ Significance, $95 \%$ Confidence Level

The results of Table 6. revealed mean values of consumer involvement and its antecedents in the three selected urban dwellings of Gujarat. The overall consumer involvement was 3.96 suggesting moderately high consumer involvement. A look at the city-wise data showed that mean values across the three selected cities were more or less similar ranging between 3.95 (Ahmedabad) and 3.99 (Vadodara).

As was ascertained through the results of factor analysis, consumer involvement had four antecedents as described in the table. Mean for the factor Knowledge $(\mathrm{K})$ was highest $(\mathrm{Mean}=4.16)$ suggesting that respondents possessed sufficient knowledge regarding organic food products. Compared to that the lowest mean value was for the factor Information Search (IS) (Mean=3.64). This value suggested that when it came to searching product related information, the opinion was moderately favourable. The mean values for the remaining two factors were above 4 suggesting positive response. A look at these factors city-wise revealed that the highest mean value was for the factor Knowledge (K) $(\mathrm{Mean}=4.26)$ while that for Information Search (IS) was the lowest (Mean=3.53). Both these values were obtained from Vadodara city, which meant that all the 
DOI: $\underline{10.51386 / 25815946 / \mathrm{ijsms}-\mathrm{v} 4 \mathrm{i} 4 \mathrm{p} 139}$

other mean values for all the other cities resided between these values. All the mean values for involvement and its antecedents were found to be highly significant. Hence, based on the results of Chi-square analysis the null hypothesis was rejected and alternate hypothesis was accepted as follows -

$\mathrm{H}_{1}$ : Consumer involvement for organic food products is highly significant in the selected urban dwellings of Gujarat.

After establishing consumer involvement for organic food products, the next step was to examine interrelationship between the antecedents of involvement and consumer involvement.

Table 7. Correlation between antecedents of involvement and consumer involvement for selected urban dwellings in Gujarat.

\begin{tabular}{|c|c|c|c|c|c|c|}
\hline & & IS & $\mathbf{K}$ & $\mathbf{B}$ & $\mathbf{E}$ & CI \\
\hline \multirow{3}{*}{ Information Search (IS) } & Pearson Correlation & 1 & & & & \\
\hline & Sig (2 tailed) & & & & & \\
\hline & $\mathbf{N}$ & 200 & & & & \\
\hline \multirow{3}{*}{ Knowledge (K) } & Pearson Correlation & $.564 * *$ & 1 & & & \\
\hline & Sig (2 tailed) & .000 & & & & \\
\hline & $\mathbf{N}$ & 200 & 200 & & & \\
\hline \multirow{3}{*}{ Belief (B) } & Pearson Correlation & $.538^{* * *}$ & .679 & 1 & & \\
\hline & Sig (2 tailed) & .000 & .000 & & & \\
\hline & $\mathbf{N}$ & 200 & 200 & 200 & & \\
\hline \multirow{3}{*}{ Emotion (E) } & Pearson Correlation & $.596^{* * *}$ & $.654 * *$ & $756^{* * *}$ & 1 & \\
\hline & Sig (2 tailed) & .000 & .000 & .000 & & \\
\hline & $\mathbf{N}$ & 200 & 200 & 200 & 200 & \\
\hline \multirow{3}{*}{ Consumer Involvement (CI) } & Pearson Correlation & $.805^{* * *}$ & $.840 * *$ & $870 * *$ & $.886^{* * *}$ & 1 \\
\hline & Sig (2 tailed) & .000 & .000 & .000 & .000 & \\
\hline & $\mathbf{N}$ & 200 & 200 & 200 & 200 & 200 \\
\hline
\end{tabular}

Sig.=Significance, $99 \%$ Confidence Level

The above table shows two kinds of relationships (i) relationship between antecedents of involvement inter-alia and (ii) antecedents of involvement and involvement. As far as relationship between antecedents of involvement was concerned, moderately high positive correlation was found. The correlation values were between 0.538 and 0.756 . The highest correlation was found between Belief (B) and Emotion (E) $(r=0.756$, $\mathrm{p}=0.000)$ while, that between Information Search (IS) and Belief (B) was the lowest $(\mathrm{r}=0.538, \mathrm{p}=0.000)$. This was an important result, previous researches have established the fact that there is a direct relation between belief and emotions (Bender, et.al., 2011) ${ }^{19}$. Jonathan Mercer (2010) observed that, emotion and cognition combine to form beliefs ${ }^{20}$. As far as relation between consumer involvement and its antecedents was concerned, high positive correlation was observed. The table shows that highest correlation was for the factor Belief (B) $(r=0.886, p=0.000)$ while, the that for Information Search (IS) was the least $(r=0.805, p=0.000)$. All these values pointed at high positive correlation.

On the basis of results obtained through Chi-square test and correlation analysis, it was clear that there exists high consumer involvement or organic food products across the three urban dwellings surveyed in this research. Correlation analysis also suggested a positive inter-relationship between all the variables. On the basis of these results, it was thought appropriate to carry out regression analysis in order to predict consumer involvement from its antecedents.

\footnotetext{
${ }^{19}$ Patrick Bender, F., Pons, P., Harris and M., Rosnay. (2011). Do young children misunderstand their own emotions?.European Journal of Developmental Psychology, 8(3), 331-348. DOI: 10.1080/17405629.2010.495615.

20 Mercer, J. (2010). Emotional beliefs. International Organisation, 64(1), 1-31. Retrieved March 01, 2021 from http://www.jstor.org/stable/40607979
} 
DOI: $\underline{10.51386 / 25815946 / \mathrm{ijsms}-\mathrm{v} 4 \mathrm{i} 4 \mathrm{p} 139}$

Volume: 4 Issue: 4

July to August 2021

https://www.ijjsmsjournal.org

Table 8. Regression Analysis for predicting consumer involvement from its antecedents for organic food products in selected urban dwellings of Gujarat.

\begin{tabular}{|l|c|r|r|r|r|}
\hline \multicolumn{5}{|c|}{ Model Summary } \\
\hline Model & R & R Square & Adjusted R Square & Std. Error of the Estimate & Durbin-Watson \\
\hline 1 & $1.000^{\mathrm{a}}$ & 1.000 & 1.000 & .00671 & 1.727 \\
\hline
\end{tabular}
a. Predictors: (Constant), IS, K, B, E
b. Dependent Variable: CI

\begin{tabular}{|l|l|r|r|r|c|c|}
\hline \multicolumn{7}{|c|}{ ANOVA $^{\mathbf{a}}$} \\
\hline \multicolumn{2}{|c|}{ Model } & Sum of Squares & \multicolumn{1}{c|}{ df } & Mean Square & \multicolumn{1}{c|}{ F } & Sig. \\
\hline \multirow{2}{*}{1} & Regression & 72.095 & 4 & 18.024 & 400028.934 & $.000^{\circ}$ \\
\cline { 2 - 7 } & Residual & .009 & 195 & .000 & & \\
\cline { 2 - 7 } & Total & 72.104 & 199 & & & \\
\hline
\end{tabular}

a. Dependent Variable: CI

b. Predictors: (Constant), IS, K, B, E

\begin{tabular}{|c|c|c|c|c|c|}
\hline \multicolumn{6}{|c|}{ Coefficients $^{\mathrm{a}}$} \\
\hline \multirow{2}{*}{ Model } & \multicolumn{2}{|c|}{ Unstandardized Coefficients } & \multirow{2}{*}{$\begin{array}{c}\text { Standardized Coefficients } \\
\text { Beta } \\
\end{array}$} & \multirow{2}{*}{$\mathbf{t}$} & \multirow{2}{*}{ Sig. } \\
\hline & B & Std. Error & & & \\
\hline (Constant) & -.002 & .003 & & -.652 & .515 \\
\hline Information Search (IS) & .251 & .001 & .318 & 308.930 & .000 \\
\hline 1 Knowledge (K) & .248 & .001 & .264 & 227.091 & .000 \\
\hline Belief (B) & .252 & .001 & .289 & 221.733 & .000 \\
\hline Emotion (E) & .249 & .001 & .305 & 232.101 & .000 \\
\hline
\end{tabular}

From the regression analysis, following model was devised -

$$
Y 1=\beta 0+\beta 1 X 1 i+\beta 2 X 2 i+\beta 3 X 3 i+\beta 4 X 4 i+\mu i(1)
$$

Where $\mathrm{Y}=$ Consumer Involvement (CI), $\mathrm{X} 1$ is Information Search (IS), $\mathrm{X} 2$ is Knowledge (K), $\mathrm{X} 3$ is Belief (B), $\mathrm{X} 4$ is Emotion (E). In this equation, $\mathrm{i}$ is the sample size ranging from 1 to 200 and $\mu$ is the random error. The regression model was -

Consumer Involvement $(C I)=-0.002+0.318 I S+0.264 \mathrm{~K}+0.289 B+0.305 E(2)$

Out of the four antecedents, 'Information Search' (IS) had the highest impact on the Consumer Involvement (CI) while, 'Knowledge' had the least impact. One important fact worth highlighting here was that all the four antecedents explained $100 \%$ variance in consumer involvement. This fact becomes clear from the model summary where both, $\mathrm{R}^{2}$ and Adjusted $\mathrm{R}^{2}$ were observed as 1 . The Durbin-Watson value for the equation was observed to be 1.727 which was in the range between 1.5 and 2.5 which is statistically acceptable. Thus, the regression model was observed to be significant on the basis of the results obtained.

\section{FINDINGS}

The purpose of this research was to ascertain a statistically correct construct to examine consumer involvement for organic food products in selected urban dwellings of Gujarat. The primary tool was designed taking into account four pre-defined dimensions. The data collected was analysed using confirmatory factor analysis (Principal Axis Factoring). Results of the factor analysis suggested that, the initial dimensions were to be re-modelled into four antecedents as 'Information Search' (IS), 'Knowledge' (K), 'Belief' (B) and 'Emotion' (E). After conducting factor analysis, the initial tool comprising 20 statements was not reduced but re-aligned on the basis of the antecedents of identified from Eigenvalues. The total variance defined by the four antecedents was found to be $65.71 \%$ which is considered appropriate for these types of studies. It was found that all antecedents individually were reliable since Cronbach alpha was between 0.750 and 0.825 . Another objective of this research was to examine the levels of involvement towards organic food products. A mean value of 3.96 indicated moderately high involvement.

A look at the city-wise mean values suggested that the values were more or less similar in all the three urban dwellings. As suggested in this research, consumer involvement depends on its antecedents or factors. In this research, the four factors confirmed had mean values ranging between 4.016 (Knowledge) and 3.64 (Information Search). Therefore, it was found that the mean values of all the factors were significantly 
DOI: $\underline{10.51386 / 25815946 / \mathrm{ijsms}-\mathrm{v} 4 \mathrm{i} 4 \mathrm{p} 139}$

instrumental in deciding the overall level of consumer involvement. It was found that involvement levels were in proportion to the mean values for antecedents. A factual justification for this was the inter-relationship between all the variables covered in this research. Correlation analysis showed that all the antecedents had high positive correlation which was significant. Previous researches have proved strong relation between beliefs and emotions which was observed in this research too $(r=0.756, p=0.00)$. Correlation also suggested that there was high positive correlation between consumer involvement and its antecedents.

Based on the key results found, a regression model was fit to predict levels of consumer involvement on the basis of its antecedents. Regression analysis showed that the model was highly reliable with the values of $\mathrm{R}$-square and adjusted R-square as 1 . The regression equation revealed that of all the antecedents, the factor 'Information Search' had maximum impact, while the factor 'Knowledge' had minimum impact on consumer involvement for organic food products. A notable observation in this research was that the unstandardised beta values in regression analysis for each antecedent taken together explained $100 \%$ impact on consumer involvement for organic food products in the selected urban dwellings in Gujarat. Durbin - Watson values further confirmed the statistical acceptability of the regression equation.

\section{CONCLUSION}

To conclude overall involvement for organic food products in the three urban dwellings of Gujarat was moderately high and from the four antecedents or factors affecting involvement, the factor information search had the highest impact on consumer involvement. This fact is an important finding for marketers of organic food products. Also, a statistically robust tool was designed, tested and validated for measuring consumer involvement.

\section{IX.DIRECTIONS FOR FURTHER RESEARCH}

This particular research was conducted in three urban dwellings of Gujarat having highest population. Further research can be conducted covering more cities. The focus of this research was organic food products wherein specifically, items of daily consumption like fruits, vegetables and grocery items only were covered. The study can be extended to cover other items as well. The tool which was validated in this research was found applicable to organic food products. Research can be undertaken to test whether this model can be applied to other product categories.

\section{REFERENCES}

[1] An Gie Yong \& Sean Pearce. (2013). A Beginner's Guide to Factor Analysis: Focussing on Exploratory Factor Analysis. Tutorials in Quantitative Methods for Psychology, Vol.9(2), 79-94. DOI: 10.20982/tqmp.09.2.p079

[2] Assael, H. (1998). Consumer Behaviour and Marketing Action. South-Western College Publishing: International Thomson Publishing.

[3] Barreto, A.M. and Ramalho, D. (2019). The Impact of Involvement on Engagement with Brand Posts. Journal of Research in Interactive Marketing, 13(3), 277-301. DOI: https://doi.org/10.1108/JRIM-01-2018-0013.

[4] C. Whan Park, David L. Mothersbaugh and Lawrence Seick. (1994). Consumer Knowledge Assessment. Journal of Consumer Research, Vol.21(1), 71-82. https://doi.org/10.1086/209383

[5] Desmet P., M, and Schifferstein H., N. (2008). Sources of Positive and Negative Emotions in Food Experience. Appetite, Vol.50(2-3), 290-301. DOI: 10.1016/j.appet.2007.08.003.Epub 2007 Aug 28.PMID:17945385.

[6] H., Assael. (1981). Consumer Behaviour and Executive Action. Boston: Kent

[7] J., A., Muncy and S., D., Hunt. (1984). Consumer Involvement: Definitional Issues and research directions. Advances in Consumer Research, 11, 193-196. DOI: https://www.acrwebsite.org/volumes/6241/volumes/v11/NA-11.

[8] J., Boote, T., Rosemary and C., Cindy. (2002). Consumer Involvement in Health Research: A Review and Research Agenda. Health Policy (Amsterdam, Netherlands), 61, 213-236. DOI: 10.1016/S0168-8510(01)00214-7.

[9] Koksal, M., H. (2020). Segmentation of Wine Consumers based on level of involvement: A Case of Lebanon. British Food Journal, 123(3), 926-942. DOI: https://doi.org/10.1108/BFJ-03-2020-0183

[10] Mercer, J. (2010). Emotional beliefs. International Organisation, 64(1), 1-31. Retrieved March 01, 2021 from http://www.jstor.org/stable/40607979 
DOI: $\underline{10.51386 / 25815946 / \mathrm{ijsms}-\mathrm{v} 4 \mathrm{i} 4 \mathrm{p} 139}$

[11] Mou, J., Zhu, W. and Benyoucef, M. (2019). Impact of Product Description and Involvement on Purchase Intention in Cross-Border E-Commerce. Industrial Management \& Data Systems, 120(3), 567-586. DOI: https://doi.org/10.1108/IMDS-05-2019-0280

[12] Patrick Bender, F., Pons, P., Harris and M., Rosnay. (2011). Do young children misunderstand their own emotions?.European Journal of Developmental Psychology, 8(3), 331-348. DOI: 10.1080/17405629.2010.495615.

[13] Petty, R.E., Unnava, R.H. \& Strathman, A.J. (1991). Theories of Attitude Change in Thomas S. Robertson and Harold H. Kasaarjian (Eds), Handbook of Consumer Behaviour, Englewood Cliffs NJ: Prentice Hall.

[14] Rachmawati, E., S. and Suroso, A. (2020). A Moderating Role of Halal Brand Awareness to Purchase Decision Making. Journal of Islamic Marketing, Vol. ahead-of-print. DOI: https://doi.org/10.1108/JIMA-05-2020-0145

[15] Salmon, C.T. (1986). Perspectives on involvement in consumer and communication research. Progress in communication sciences, 7,243-268.

[16] Schiffman, L.G. and Kanuk, L.L. (1994) Consumer Behaviour. Prentice-Hall, Englewood Cliffs.

[17] Sridharan, R., Jyothi, K. T. and Rajakumar, C.S. (2008). Role of Involvement in Predicting Brand Loyalty. Asia Pacific Business Review, 4(1), 44-58. DOI: https://doi.org/10.1177/097324700800400105

[18] Stephanie Glen, "Kaiser-Meyer-Olkin" (KMO) Test for Sampling Adequacy from Statistics How To: Elementary Statistics for the rest of us! https://www.statisticshowto.com/kaiser-meyer-olkin/

[19] Ying-Ping Liang. (2012). The Relationship between Consumer Product Involvement, Product Knowledge and Impulsive Buying Behaviour. Procedia - Social and Behavioural Sciences, Vol.57, 325-330. https://doi.org/10.1016/j.sbspro.2012.09.1193

[20] Zaichkowsky, J. L. (1985). Measuring the involvement construct. Journal of Consumer Research, 12, 341-352. https://doi.org/10.108 